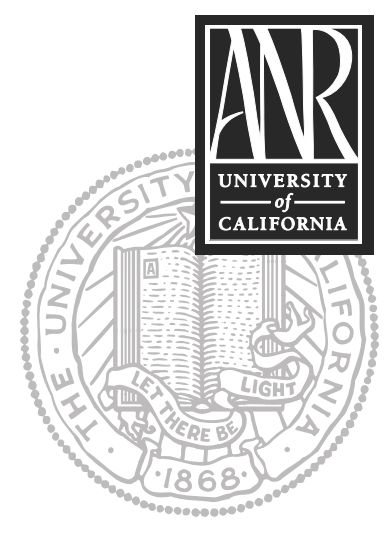

UNIVERSITY OF CALIFORNIA

Division of Agriculture and Natural Resources http://anrcatalog.ucdavis.edu

\title{
NUTRITION AND HEALTH INFO SHEET St. John's Wort
}

ERIN DIGITALE, Department of Nutrition, University of California, Davis; CRISTY HATHAWAY, Research Assistant, Department of Nutrition, University of California, Davis; KARRIE HENEMAN, Assistant Project Scientist, Department of Nutrition, University of California, Davis; SHERI ZIDENBERG-CHERR, UC Cooperative Extension Nutrition Science Specialist, Department of Nutrition, University of California, Davis

In recent years a significant amount of public interest in alternative medicines has focused on the use of St. John's wort as an antidepressant. Consumers may be attracted to this product because it is available over the counter and is perceived as safe or natural. ${ }^{1}$ St. John's wort is one of the most extensively studied herbal medications available. Research has examined its safety, mechanism of action, product purity, and efficacy in comparison with conventional antidepressants. (Only a clinical physician, however, should diagnose and treat depression.)

\section{What is St. John's wort?}

St. John's wort, also known by the Latin name Hypericum perforatum, is a plant with bright yellow-orange flowers. Both leaves and flowers may be incorporated into medicinal preparations. ${ }^{2}$

\section{Is St. John's wort an effective antidepressant?}

Clinical trials of St. John's wort usually compare it with placebo (sugar pill) or a tricyclic antidepressant. Tricyclic antidepressants (TCAs) are synthetic antidepressants often used to treat mild to moderate depression. ${ }^{2}$

\section{For treatment of mild to moderate depression}

Studies of patients experiencing mild to moderate clinical depression have generally concluded that short-term use of St. John's wort is more effective than placebo, and that it is as effective as low doses of TCAs. Additionally, studies have found that short-term use of St. John's wort produces fewer side effects than TCAs, which may result in increased patient compliance. ${ }^{3}$

\section{For treatment of major depression}

In addition to the large number of studies investigating mild or moderate depression, a few studies have examined the efficacy of St. John's wort in treating major depression. ${ }^{4}$ These studies have not found significant treatment effects, and researchers have therefore concluded that patients with major depression do not benefit from St. John's wort. Synthetic antidepressants (such as selective serotonic reuptake inhibitors, or SSRIs) are significantly more effective than St. John's wort for the treatment of major depression.

\section{How does St. John's wort work?}

The antidepressant mechanism of St. John's wort is not well understood. Hyperforin and hypericin are two compounds contained in this herb that are thought to have pharmacological activity. Several compounds in St. John's wort may be acting synergistically to produce the drug's effects, with no single compound being solely responsible for antidepressant activity. ${ }^{5}$ The antidepressant effect is thought to result from selective inhibition of serotonin, dopamine, and norepinephrine reuptake in the central nervous system. ${ }^{6}$ 


\section{Does the use of St. John's wort produce side effects?}

Newly pregnant women and those attempting to conceive should be advised to discontinue use of St. John's wort, as damage to reproductive eggs may occur with use of high dosages, and sperm motility may be inhibited in men. Pregnant women with normal hormonal mood swings, and women with a history of postnatal depression are advised to ask maternity staff about its use. No adverse events have been seen with St. John's wort and breast-feeding; however, no long-term studies have been conducted regarding the effects the herb may have on infants. ${ }^{7}$ When used as a monotherapy, the reported incidence of side effects for St. John's wort is lower than for synthetic antidepressants. In clinical trials, mild side effects have included headache, fatigue, gastrointestinal upset, and restlessness. ${ }^{3}$ Potentially serious side effects of St. John's wort include photosensitivity, which is rare, and induction of manic symptoms in predisposed patients. ${ }^{6}$

\section{Is it safe to combine St. John's wort with other medications?}

When combined with other medications, St. John's wort can pose serious health concerns. This is because it increases the rate of metabolism of several types of synthetic drugs. Plasma levels of a variety of drugs can be decreased as a result.

\begin{tabular}{|c|c|c|c|}
\hline Drug(s) affected & $\begin{array}{l}\text { Purpose of affected } \\
\text { drug(s) }\end{array}$ & $\begin{array}{l}\text { Adverse effects documented when } \\
\text { combined with SJW }\end{array}$ & Reference \\
\hline $\begin{array}{l}\text { Warfarin, Coumarin, } \\
\text { Phenprocoumon }\end{array}$ & anticoagulants & $\begin{array}{l}\text { lowering of serum warfarin and } \\
\text { phenprocoumon levels; reduced response to } \\
\text { warfarin }\end{array}$ & $8,9,10$ \\
\hline Oral contraceptives & $\begin{array}{l}\text { contraceptive, regulator of } \\
\text { menstrual cycle }\end{array}$ & $\begin{array}{l}\text { breakthrough bleeding; } \\
\text { (no unwanted pregnancies documented) }\end{array}$ & 9,12 \\
\hline Amitriptyline, nortriptyline & antidepressants & $\begin{array}{l}\text { lowering of serum amitriptyline and } \\
\text { nortriptyline levels by } 22-40 \text { percent }\end{array}$ & 8 \\
\hline Digoxin & anti-arrhythmic, cardiotonic & lowering of serum digoxin levels & 8,9 \\
\hline Indinavir & HIV protease inhibitor & lowering of serum indinavir levels & 13 \\
\hline Cyclosporin & $\begin{array}{l}\text { immunosuppressant (prevent } \\
\text { rejection of organ transplant) }\end{array}$ & $\begin{array}{l}\text { lowering of serum cyclosporin levels; acute } \\
\text { heart transplant rejection }\end{array}$ & $8,9,14$ \\
\hline $\begin{array}{l}\text { SSRIs (selective serotonin } \\
\text { reuptake inhibitors) }\end{array}$ & antidepressants & $\begin{array}{l}\text { symptoms of central serotonin excess, } \\
\text { especially in elderly patients }\end{array}$ & 15 \\
\hline
\end{tabular}

Patients who are stabilized on treatment regimes that combine St. John's wort with other medications should not discontinue their St. John's wort without medical supervision, as this could cause dangerous changes in the pharmacokinetics of their other medications. ${ }^{11}$ In addition, since St. John's wort affects a variety of enzymes and transporters involved in drug metabolism, the drugs whose metabolism could potentially be changed by St. John's wort extend far beyond those listed in the table. Patients should consult a knowledgeable physician before combining St. John's wort with any other medications.

\section{Are St. John's wort products quality-controlled?}

St. John's wort is classified as a dietary supplement under the Dietary Health Education and Supplement Act of 1994. Supplements are not subject to the same regulatory procedures as conventional drugs. ${ }^{16}$ Since St. John's wort products are prepared from extracts of plant matter, the dose of active compounds present in each preparation is uncertain. Thus, the potency of St. John's wort supplements varies significantly from manufacturer to manufacturer and between batches prepared by the same manufacturer. $^{5}$ 


\section{What can we conclude about St. John's wort?}

In general, clinical trials have found that St. John's wort is an effective antidepressant for persons experiencing mild to moderate depression, with an efficacy similar to tricyclic antidepressants and significantly greater than placebo. However, St. John's wort has been found ineffective for those suffering from major depression. St. John's wort has fewer side effects than tricyclic antidepressants, which may improve patient compliance with this antidepressant regimen. The most serious safety concerns related to the use of St. John's wort are its ability to modify the metabolism of other medications and the lack of standardization in the levels of active compounds in St. John's wort products, which makes accurate dosing difficult.

\section{REFERENCES}

1. Wagner, P. J., D. Jester, B. LeClair, A. T. Taylor, L. Woodward, and J. Lambert. 1999. Taking the edge off: Why patients choose St. John's wort. The Journal of Family Practice 48(8): 615-619.

2. Pilkington, K., A. Boshnakova, and J. Richardson. 2006. St. John's wort for depression: Time for a different perspective? Complementary Therapies in Medicine 14(4): 268-281.

3. Malatay, W. 2005. St. John's wort for depression. American Family Physician 71(7). American Academy of Physicians Web site, http://www.aafp.org/ afp/20050401/fpin.html.

4. Shelton, R. C., M. B. Keller, A. Gelenberg, D. L. Dunner, R. Hirschfeld, M. E. Thase, J. Russell, R. B. Lydiard, P. Crits-Christoph, R. Gallop, L. Todd, D. Hellerstein, P. Goodnick, G. Keitner, S. M. Stahl, and U. Halbreich. 2001. Effectiveness of St. John's wort in major depression: A randomized controlled trial. Journal of the American Medical Association 285(15): 1978-1986.

5. Wurglics, M., K. Westerhoff, A. Kaunzinger, A. Wilke, A. Baumeister, and J. Dressman. 2001. Batch-to-batch reproducibility of St. John's wort preparations. Pharmacopsychiatry 34 (Supp 11): S152-S156.

6. Ernst, E. 2002. The risk-benefit profile of commonly used herbal therapies: Ginkgo, St. John's wort, ginseng, echinacea, saw palmetto, and kava. Annals of Internal Medicine 136:42-53.

7. Tiran, D. 2003. The use of herbs by pregnant and childbearing women: A risk-benefit assessment. Complementary Therapies in Nursing and Midwifery 9(4): 176-181.

8. Kasper, S. 2001. Hypericum perforatum: A review of clinical studies. Pharmacopsychiatry 34 (Supp 11): S51-S55.

9. Ernst, E. 1999. Second thoughts about safety of St. John's wort. The Lancet 345:2014-2015.

10. Maurer, A., A. Johne, and S. Bauer. 1999. Interaction of St. John's wort extract with phenprocoumon. Abstract. European Journal of Clinical Pharmacology 55: A22.

11. Wheatley, D. 2000. Safety of St. John's wort (Hypericum perforatum). The Lancet 355:575-576.

12. Yue, Q. Y., C. Bergquist, and B. Gerden. 2000. Safety of St. John's wort (Hypericum perforatum). The Lancet 355:576-577.

13. Piscitelli, S. C., A. H. Burstein, D. Chaitt, R. M. Alfaro, and J. Falloon. 2000. Indinavir concentrations and St. John's wort. The Lancet 355:547-548. 
14. Ruschitzka, F., P. J. Meier, M. Turina, T. F. Lüscher, and G. Noll. 2000. Acute heart transplant rejection due to St. John's wort. The Lancet 355:548-549.

15. Martin, T. G. 1996. Serotonin syndrome. Annals of Emergency Medicine 28:520-526.

16. Kaczka, K. 2000. From herbal prozac to Mark McGwire's tonic: How the Dietary Supplement, Health and Education Act changed the regulatory landscape for health products. Journal of Contemporary Health Law and Policy 16:463-499.

\section{FOR FURTHER INFORMATION}

To order or obtain ANR publications and other products, visit the ANR

Communication Services online catalog at http://anrcatalog.ucdavis.edu. You can also place orders by mail, phone, or FAX, or request a printed catalog of our products from

University of California

Agriculture and Natural Resources

Communication Services

6701 San Pablo Avenue, 2nd Floor

Oakland, California 94608-1239

Telephone: (800) 994-8849 or (510) 642-2431

FAX: (510) 643-5470

E-mail inquiries: danrcs@ucdavis.edu

An electronic version of this publication is available on the ANR Communication Services Web site at http://anrcatalog.ucdavis.edu.

This publication has been anonymously peer reviewed for technical accuracy by University of California scientists and other qualified professionals. This review process was managed by the ANR Associate Editor for Food and Nutrition.

\section{Publication 8137}

ISBN-13: 978-1-60107-494-2

(C) 2008 The Regents of the University of California

Division of Agriculture and Natural Resources

All rights reserved.

No part of this publication may be reproduced, stored in a retrieval system, or transmitted, in any form or by any means, electronic, mechanical, photocopying, recording, or otherwise, without the written permission of the publisher and the authors.

The University of California prohibits discrimination or harassment of any person on the basis of race, color, national origin, religion, sex, gender identity, pregnancy (including childbirth, and medical conditions related to pregnancy or childbirth), physical or mental disability, medical condition (cancer-related or genetic characteristics), ancestry, marital status, age, sexual orientation, citizenship, or status as a covered veteran (covered veterans are special disabled veterans, recently separated veterans, Vietnam era veterans, or any other veterans who served on active duty during a war or in a campaign or expedition for which a campaign badge has been authorized) in any of its programs or activities. University policy is intended to be consistent with the provisions of applicable State and Federal laws.

Inquiries regarding the University's nondiscrimination policies may be directed to the Affirmative Action/Staff Personnel Services Director, University of California, Agriculture and Natural Resources, 1111 Franklin Street, 6 $6^{\text {th }}$ Floor, Oakland, CA 94607-5201, (510) 987-0096. For information about ordering this publication, telephone 1-800-994-8849.

pr-1/08-LR/CM 